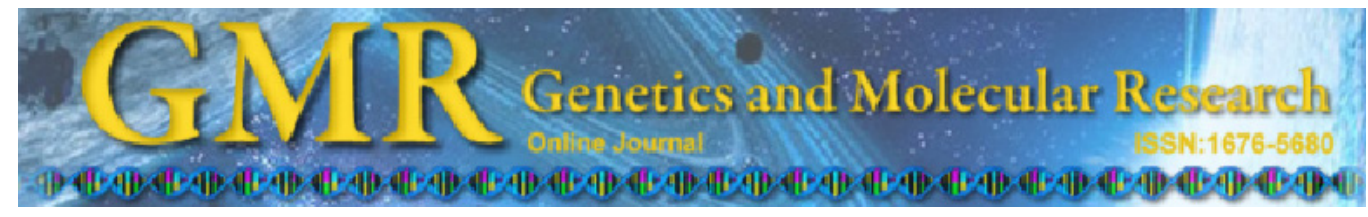

\title{
Expression of growth genes in response to glycerol use in Japanese quail diets
}

\author{
E. Gasparino', A.R. Oliveira Neto ${ }^{2}$, A.P. Del Vesco ${ }^{1}$, A.V. Pires ${ }^{3}$, \\ E. Batista ${ }^{1}$, D.M. Voltolini ${ }^{1}$ and K.R.S. Souza ${ }^{4}$ \\ ${ }^{1}$ Departamento de Zootecnia, Universidade Estadual de Maringá, \\ Maringá, PR, Brasil \\ ${ }^{2}$ Evonik Degussa do Brasil, São Paulo, SP, Brasil \\ ${ }^{3}$ Departamento de Zootecnia, \\ Universidade Federal dos Vales do Jequitinhonha e de Mucuri, \\ Diamantina, MG, Brasil \\ ${ }^{4}$ Departamento de Zootecnia, Universidade Federal de Viçosa, \\ Viçosa, MG, Brasil \\ Corresponding author: E. Gasparino \\ E-mail: egasparino@uem.br
}

Genet. Mol. Res. 11 (3): 3063-3068 (2012)

Received October 26, 2011

Accepted May 24, 2012

Published August 31, 2012

DOI http://dx.doi.org/10.4238/2012.August.31.3

\begin{abstract}
Glycerol can be used as a substitute for corn for feeding poultry, but there are concerns about how it may affect growth performance and health of the birds. We evaluated the expression of mRNA of growth hormone $(\mathrm{GH})$ and insulin-like growth factor I (IGF-I) in 35-day-old Japanese quails fed different glycerol levels ( 0 , 4 , and $8 \%$ dietary glycerol instead of corn). Total RNA was extracted from the breast muscle and cDNA was amplified with the use of specific primers for these genes using real-time PCR. Quails fed the diet with $8 \%$ glycerol supplementation had significantly lower $\mathrm{GH}$ mRNA and IGF-I mRNA expression than those fed no glycerol or $4 \%$ glycerol. No significant effect of the treatments was found on quail weight gain or feed intake. Feed conversion ratio was influenced
\end{abstract}


by dietary glycerol levels: the group fed $8 \%$ glycerol displayed the worst feed conversion ratio (2.54) compared with that of quail fed the control diet (2.35) or 4\% glycerol (2.36). Considering quail performance and the expression of the genes GH and IGF-I, a level of $4 \%$ glycerol can be used in quail feeding without any harmful effects.

Key words: Breast muscle; GH; IGF-I

\section{INTRODUCTION}

Genetic improvement has promoted significant developments in poultry performance during recent decades (Havenstein et al., 2003). The genetic evolution of poultry and other livestock, such as pigs and cattle, has been based on selection for feed conversion (efficiency of converting feed into muscle) and has been a key factor in obtaining animals with lower feed residue intake (Archer et al., 1999; Castro Bulle et al., 2007; Krueger et al., 2008; Bottje and Carstens, 2009).

Studies have shown that animals that are less efficient in converting feed into body weight may display changes in the activity of the sodium and potassium pump, the expression of genes of the electron transport chain, and the concentrations of important hormones such as insulin-like growth factor I (IGF-I), growth hormone (GH), thyroxin, triiodothyronine, and corticosterone. These changes may influence nutrient utilization and basal metabolism, alter body energy expenditure, and consequently, affect caloric increment of animals (Curtis, 1983; Rosebrough and McMurtry, 1993; Yunianto et al., 1997; Johnson et al., 2003; Bottje and Carstens, 2009).

Glycerol was chosen for this study because it is becoming available in large quantities owing to biodiesel production using vegetal sources such as soybean oil. According to Doppenberg and Van Der Aar (2007) and Dozier et al. (2008), glycerol can be used effectively in poultry diets as an energy source. However, broilers fed diets containing more than $10 \%$ glycerol have displayed performance problems (Cerrate et al., 2006). The physiologic effect of this large quantity of glycerol is incompletely understood, especially on a molecular basis, such as gene messenger RNA (mRNA) expression. This study was developed to evaluate the effect of dietary glycerol inclusion on the mRNA expression of GH and IGF-I in the breast muscle of 35-day-old quails.

\section{MATERIAL AND METHODS}

Four hundred and fifty-one-day-old Japanese quails with the same weight were distributed in a completely randomized experimental design into 3 treatments $(0,4$, or $8 \%$ crude glycerol in the feed) with 5 replicates of 30 birds per experimental unit. Birds were housed in a conventional house in $2.5-\mathrm{m} 2$ pens with rice husk litter. A continuous light program was applied throughout the experimental period.

Three feeds were formulated containing 0 (control), 4, and 8\% crude glycerol. All feeds were based on corn and soybean meal according to the nutritional requirements proposed by Rostagno et al. (2005) and the National Research Council (1994) (Table 1). 
Table 1. Ingredient and calculated composition of the experimental diets (\%, as-fed basis).

\begin{tabular}{lccc}
\hline & No glycerol & $4 \%$ glycerol & $8 \%$ glycerol \\
\hline Ingredients & & & \\
Soybean meal & 50.59 & 51.35 & 52.12 \\
Corn & 40.24 & 36.21 & 32.17 \\
Soybean oil & 4.84 & 4.12 & 8.40 \\
Glycerol & 0.00 & 4.00 & 1.57 \\
Dicalcium phosphate & 1.55 & 1.56 & 0.66 \\
DL-methionine & 0.65 & 0.66 & 0.62 \\
L-lysine & 0.65 & 0.64 & 0.35 \\
L-threonine & 0.35 & 0.35 & 0.40 \\
Salt & 0.40 & 0.40 & 0.34 \\
Limestone & 0.36 & 0.35 & 0.35 \\
Premix & 0.35 & 0.35 & 27.52 \\
Calculated composition (\%) & & 27.52 & 1.88 \\
Crude protein & 27.52 & 1.88 & 1.44 \\
Lysine & 1.88 & 1.44 & 1.22 \\
Met+Cys & 1.44 & 1.22 & 0.30 \\
Threonine & 1.22 & 0.30 & 0.30 \\
Tryptophan & 0.30 & 0.24 & 0.65 \\
Sodium & 0.18 & 0.65 & 0.41 \\
Calcium & 0.65 & 0.41 & 3.000 \\
Available phosphorus & 0.41 & 3.000 & \\
AME (kcal/kg) & 3.000 & &
\end{tabular}

$\mathrm{AME}=$ apparent metabolizable energy.

Birds were weighed at 35 days of age to determine body weight gain. The experimental feeds and feed residues were weighed to calculate feed intake. Feed conversion was calculated as the ratio of feed intake to weight gain. Mortality was considered in the calculation of the feed conversion ratio.

Ten birds per treatment were killed via cervical dislocation at 35 days of age. A sample of breast muscle (pectoralis superficialis) was collected and stored in an RNA Holder ${ }^{\circledR}$ (BioAgency, Brazil) at $-20^{\circ} \mathrm{C}$ until RNA extraction.

Total RNA was extracted using Trizo ${ }^{\circledR}$ (Invitrogen, Carlsbad, CA, USA) according to manufacturer recommendations. SuperScript ${ }^{\mathrm{TM}}$ III First-Strand Synthesis Super Mix (Invitrogen) was used to produce complementary DNA. SYBR GREEN (SYBR ${ }^{\circledR}$ GREEN PCR Master Mix (Applied Biosystems, USA) was used for real-time polymerase chain reaction analysis. GH (sense primer, 5'-GCTGCCGAGACATACAAAGAG-3'; antisense primer, 5'-GAGCTGGGATGGTTTCTGAG-3'; fragment size, $109 \mathrm{bp}$; annealing, $60^{\circ} \mathrm{C}$ ), IGF-I (sense primer, 5'-CACCTAAATCTGCACGCT-3'; antisense primer, 5'-CTTGTGGATGGCATGATC T-3'; fragment size, $140 \mathrm{bp}$; annealing, $60^{\circ} \mathrm{C}$ ), and $\beta$-actin (sense primer, $5^{\prime}$-ACCCCAAAGCC AACAGA-3'; antisense primer, 5'-CCAGAGTCCATCACAATACC-3'; fragment size, 136 $\mathrm{bp}$; annealing, $60^{\circ} \mathrm{C}$ ) primers were designed according to the sequences deposited in GenBank (accession Nos. FJ458436, FJ977570.1, and L08165, respectively) using the website [www. idtdna.com; accessed January 21, 2012]. All analyses were carried out in a final volume of 25 $\mu \mathrm{L}$ and in duplicate.

Data were analyzed using the GLM procedures of the SAS statistical package. The UNIVARIATE procedure was applied to verify the normality of gene expression residues (expressed as $\left.2^{-\mathrm{ACt}}\right)$ and production data. All genes evaluated were $\log$ transformed $(\ln [\mathrm{x}+1])$ (Voge et al., 2004) because they did not comply with normality assumptions. Data were submitted to analysis of variance, with 3 treatments and 10 replicates per treatment. Means were compared using the Tukey test $(\mathrm{P}<0.05)$. 


\section{RESULTS}

The performance of 1- to 35-day-old quails fed various dietary glycerol levels is shown in Figure 1. No significant effect of the treatments was found on quail weight gain or feed intake; however, a trend for higher feed intake and lower weight gain was observed in birds fed $8 \%$ glycerol. Conversely, feed conversion ratio was influenced by dietary glycerol levels: the group fed $8 \%$ glycerol displayed the worst feed conversion ratio (2.54) compared with that of quail fed the control diet (2.35) or 4\% glycerol (2.36).
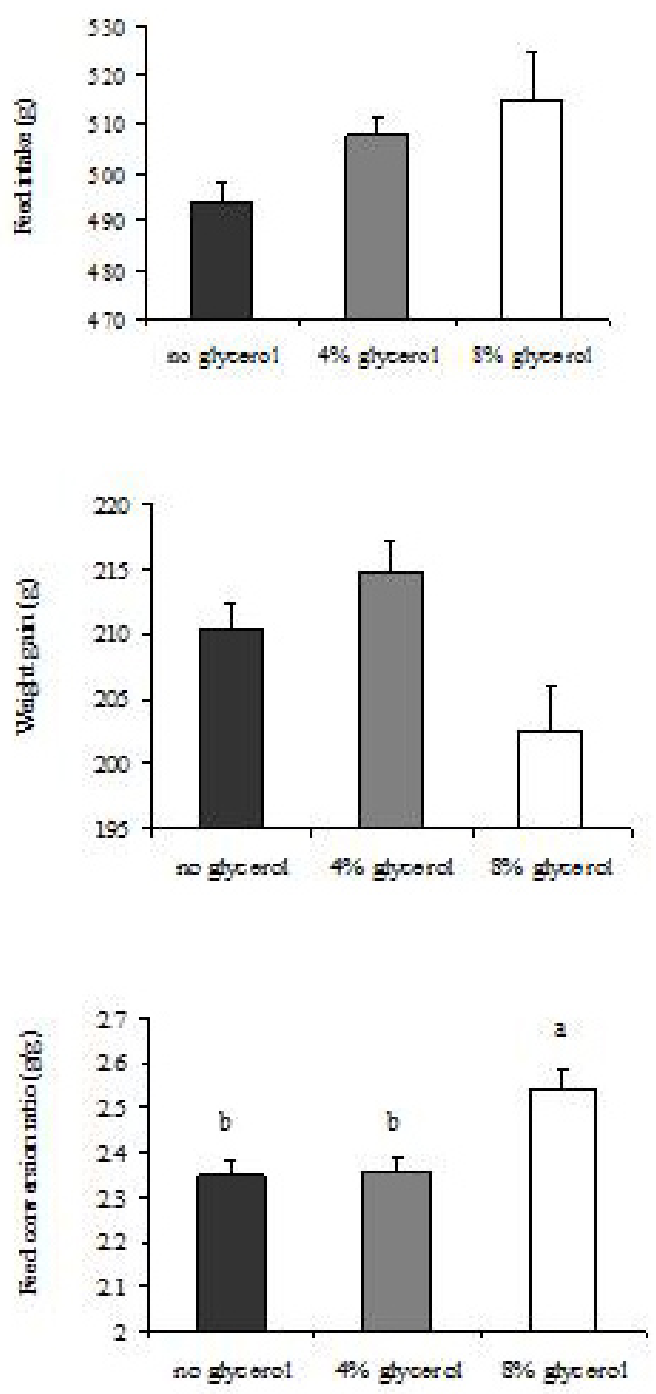

Figure 1. Feed intake, weight gain, and feed conversion ratio of 35-day-old quails submitted to different glycerol dietary treatments. Letters above the bars represent the comparison among treatment means. Different letters indicate statistical difference $(\mathrm{P}<0.05)$ by the test of Tukey. 
GH and IGF-I mRNA expression in the breast muscle of 35-day-old quails is shown in Figure 2. Birds receiving a 4\% glycerol diet showed higher GH mRNA expression in the breast muscle relative to those fed the control diet and diet with inclusion of $8 \%$ glycerol. The $8 \%$ glycerol diet negatively influenced IGF-I mRNA expression, which was reduced compared to that of the control diet and $4 \%$ glycerol diet. Birds in the treatment group fed $4 \%$ glycerol displayed IGF-I mRNA expression similar to those in the group fed control diet.

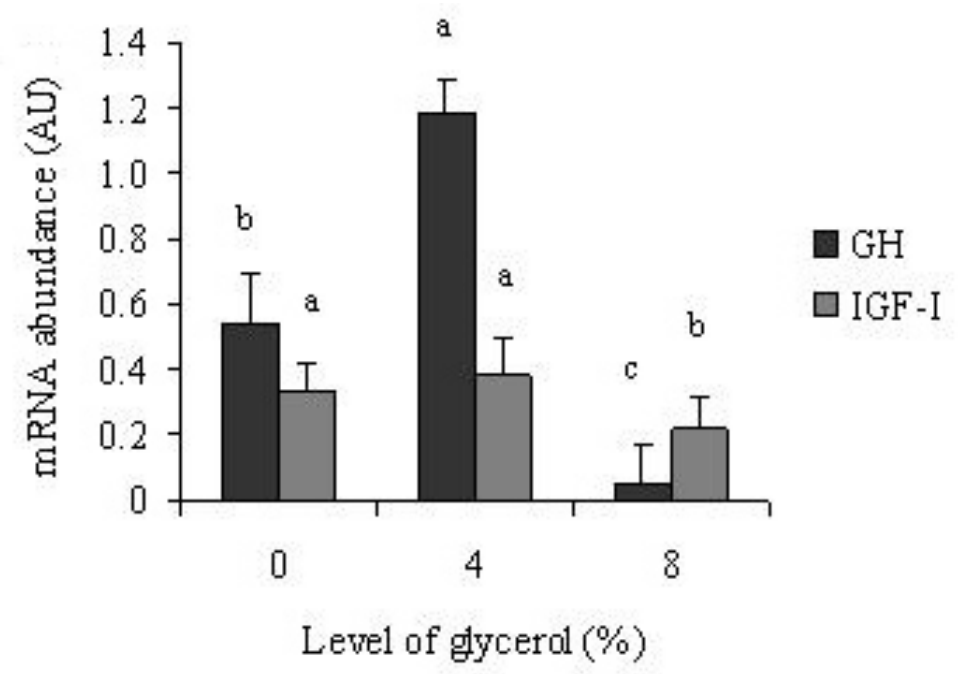

Figure 2. Messenger RNA (mRNA) expression of growth hormone (GH) and insulin-like growth factor (IGF-I) in 35-day-old quails fed different glycerol levels. Letters above the bars represent the comparison among mRNA expression means. Different letters indicate statistical difference $(\mathrm{P}<0.05)$ by the Tukey test.

\section{DISCUSSION}

To the best of our knowledge, our study is the first to examine the mRNA expression of GH in the breast muscle of quail. Our previous research showed that, unlike the expression in quail, no GH mRNA expression occurs in the breast muscle of broilers (data not shown). The present study showed the effects of various levels of glycerol on GH as well as IGF-I mRNA expression and bird performance. As mentioned, the results likely occurred because glycerol could not replace starch (corn) and oil (soybean oil) as an energy source, mainly at the highest level used, what resulted in lower IGF-I mRNA expression. We have found no results in the literature to confirm this effect and the physiological mechanism of glycerol on GH and IGF-I mRNA expression in the breast muscles of any avian species.

Studies conducted by Scanes et al. (1981) and Lauterio and Scanes (1988) have confirmed that fasting birds and those consuming diets with some nutrient restrictions (protein or energy) display reduced IGF-I mRNA expression. Rosebrough and McMurtry (1993) have also observed lower plasmatic IGF-I levels in broilers under nutrient restriction. Broilers receiving fewer nutrients in their diets demonstrated decreased performance.

This study is also the first and the only examination of the effects of glycerol on mRNA expression in GH and IGF-I mRNA genes in breast muscle. Information about how 
nutrient levels influence mRNA expression and bird performance is infrequently published in literature and stimulates further studies in this field that are apt to make major contributions to our understanding of bird physiology.

\section{ACKNOWLEDGMENTS}

Research supported by PROCAD - CAPES and FAPEMIG. A.V. Pires was the recipient of CNPq and FAPEMIG fellowships.

\section{REFERENCES}

Archer JA, Richardson EC, Herd RM and Arthur PF (1999). Potential for selection to improve efficiency of feed use in beef cattle: a review. Aust. J. Agric. Res. 50: 147-161.

Bottje WG and Carstens GE (2009). Association of mitochondrial function and feed efficiency in poultry and livestock species. J. Anim. Sci. 87: E48-E63.

Castro Bulle FC, Paulino PV, Sanches AC and Sainz RD (2007). Growth, carcass quality, and protein and energy metabolism in beef cattle with different growth potentials and residual feed intakes. J. Anim. Sci. 85: 928-936.

Cerrate S, Yan F, Wang Z, Coto C, et al. (2006). Evaluation of glycerine from biodisel production as a feed ingredient for broilers. Int. J. Poult. Sci. 11: 1001-1007.

Curtis SE (1983). Environmental Management in Animal Agriculture. Iowa State University Press, Ames, Iowa.

Doppenberg J and Van Der Aar P (2007). The Nutritional Value of Biodiesel By-Products. Part 2: Glycerine. A HighEnergy Liquid Product, Glycerine Offers Livestock Producers the Option of a Cost Effective, Alternative Feed Ingredient. Feed Business Asia, 42-43.

Dozier WA, III, Kerr BJ, Corzo A, Kidd MT, et al. (2008). Apparent metabolizable energy of glycerin for broiler chickens. Poult Sci. 87: 317-322.

Havenstein GB, Ferket PR and Qureshi MA (2003). Growth, livability, and feed conversion of 1957 versus 2001 broilers when fed representative 1957 and 2001 broiler diets. Poult Sci. 82: 1500-1508.

Johnson DE, Ferrell CL and Jenkins TG (2003). The history of energetic efficiency research: Where have we been and where are we going? J. Anim. Sci. 81 (Suppl 1): E27-E38.

Krueger WK, Carstens GE, Lancaster PA and Slay LJ (2008). Relationship between residual feed intake and apparent nutrient digestibility in growing calves. J. Anim. Sci. 86: 25.

Lauterio TJ and Scanes CG (1988). The role of thyroid hormones in the growth hormone response to protein restriction in the domestic fowl (Gallus domesticus). J. Endocrinol. 117: 223-228.

National Research Council (1994). Nutrient Requirement of Poultry. 9th Revised Edition. National Academy Press, Washington.

Rosebrough RW and McMurtry JP (1993). Protein and energy relationships in the broiler chicken. Effects of protein quantity and quality on metabolism. Br. J. Nutr. 70: 667-678.

Rostagno HS, Albino LFT, Donzele JL and Gomes PC (2005). Brazilian Tables for Poultry and Swine: Composition of Feedstuffs and Nutritional Requirements. $2^{\mathrm{a}}$ ed. Departamento de Zootecnia, Universidade Federal de Viçosa, Viçosa.

Scanes CG, Griminger P and Buonomo FC (1981). Effects of dietary protein restriction on circulating concentrations of growth hormone in growing domestic fowl (Gallus domesticus). Proc. Soc. Exp. Biol. Med. 168: 334-337.

Voge JL, Santiago CA, Aad PY, Goad DW, et al. (2004). Quantification of insulin-like growth factor binding protein mRNA using real-time PCR in bovine granulosa and theca cells: effect of estradiol, insulin, and gonadotropins. Domest. Anim. Endocrinol. 26: 241-258.

Yunianto VD, Hayashi K, Kaneda S, Ohtsuka A, et al. (1997). Effect of environmental temperature on muscle protein turnover and heat production in tube-fed broiler chickens. Br. J. Nutr. 77: 897-909. 